\title{
Treatment of Dravet Syndrome
}

\author{
Elaine C. Wirrell
}

\begin{abstract}
Dravet syndrome is among the most challenging electroclinical syndromes. There is a high likelihood of recurrent status epilepticus; seizures are medically refractory; and patients have multiple co-morbidities, including intellectual disability, behaviour and sleep problems, and crouch gait. Additionally, they are at significant risk of sudden unexplained death. This review will focus predominantly on the prophylactic medical management of seizures, addressing both first-line therapies (valproate and clobazam) as well as second-line (stiripentol, topiramate, ketogenic diet) or later options (levetiracetam, bromides, vagus nerve stimulation). Sodium channel agents_including carbamazepine, oxcarbazepine, phenytoin and lamotrigine-should be avoided, as they typically exacerbate seizures. Several agents in development may show promise, specifically fenfluramine and cannabidiol, but they need further evaluation in randomized, controlled trials. In addition to prophylactic treatment, all patients need home-rescue medication and a status epilepticus protocol that can be carried out in their local hospital. Families must be counselled on non-pharmacologic strategies to reduce seizure risk, including avoidance of triggers that commonly induce seizures (including hyperthermia, flashing lights and patterns). In addition to addressing seizures, holistic care for a patient with Dravet syndrome must involve a multidisciplinary team that includes specialists in physical, occupational and speech therapy, neuropsychology, social work and physical medicine.
\end{abstract}

Keywords: Antiepileptic drug, Dravet syndrome, ketogenic diet, stiripentol

doi:10.1017/cjn.2016.249

Can J Neurol Sci. 2016; 43: S13-S18

Dravet syndrome (DS) is an intractable paediatric electroclinical syndrome beginning in the first 24 months of life, with generalized or hemi-convulsive seizures initiated by fever (often associated with vaccines) or hyperthermia, which are often prolonged. In early childhood, between 1 and 5 years of age, other seizure types emerge, including myoclonic, atypical absence and focal seizures, as well as periods of obtundation (non-convulsive) status epilepticus. This review will outline treatment goals and the first-, second-line and later therapies for seizures (pharmacologic and non-pharmacologic) and agents in development, as well as address management of status epilepticus.

\section{Treatment Goals}

In managing patients with DS, the aim is to significantly reduce seizure frequency (particularly prolonged events) and limit antiepileptic drug toxicity. Complete seizure cessation is rarely achievable. Another therapeutic goal is to minimize co-morbidities, including intellectual disability, behavioural and psychiatric problems, seizure-related injury and sudden unexplained death in epilepsy (SUDEP). A greater degree of cognitive and behavioural impairment has been linked to both higher frequency of convulsive $^{1}$ and non-convulsive seizures. ${ }^{2,3}$

The typical seizure pattern changes over time. Status epilepticus is most problematic during the first two years of life and reduces in frequency after five years of age. In early childhood, frequent non-convulsive seizures may negatively impact development. In the adolescent and adult years, frequent but brief nocturnal generalized convulsive seizures are most common and place the patient at risk of SUDEP.

Provocation of seizures by hyperthermia, and less frequently by photosensitivity or pattern sensitivity, is commonly noted. Antipyretics for fever, minimizing warm baths or exercise on warm days, and avoiding photosensitivity triggers are recommended.

\section{Prophylactic Seizure Management (see Table 1)}

Treatment of DS should begin when this diagnosis is suspected, rather than waiting for genetic confirmation. Importantly, certain antiepileptic agents should be avoided, as they have been clearly shown to exacerbate seizures in DS. These include carbamazepine, ${ }^{4}$ oxcarbazepine, phenytoin, lamotrigine, ${ }^{5}$ vigabatrin, ${ }^{4}$ phenobarbital ${ }^{6,7}$ and rufinamide. ${ }^{8}$

There have been few evidence-based studies to evaluate the best therapies for DS, and recommendations for most first- and second-line therapies are based predominantly on expert opinion and a limited number of small, mostly retrospective, open-label studies. Only one agent, stiripentol, has published evidence of level 2 efficacy, based on placebo-controlled, randomized, doubleblind studies. ${ }^{9}$ However, preliminary data from a randomized, placebo-controlled, double-blind study on cannabidiol also provide level 2 evidence of efficacy (gwpharma.com), although these data are not yet published. Open-label prospective studies have also been performed using topiramate ${ }^{10,11}$ and levetiracetam. ${ }^{12}$ The Oxford Center for Evidence-Based Medicine has defined five levels of evidence to determine therapeutic benefit, ranging from the highest (level 1: evidence of efficacy based on a systemic review of randomized trials) to the lowest (level 5: evidence of efficacy based on mechanism-based reasoning only). ${ }^{13}$ For each

From the Department of Child and Adolescent Neurology, the Mayo Clinic, Rochester, Minnesota, USA.

Received February 12, 2016. Final Revisions Submitted May 9, 2016. Correspondence to: Elaine Wirrell, Child and Adolescent Neurology, Mayo Clinic, 200 First Street SW, Rochester, Minnesota 55905, USA. Email: wirrell.elaine@mayo.edu. 
Table 1: Second-line medications in Dravet Syndrome

\begin{tabular}{|c|c|c|c|c|}
\hline Author & Study design & $\begin{array}{l}\text { Level of } \\
\text { evidence* }\end{array}$ & AED & Outcome \\
\hline \multicolumn{5}{|l|}{ Stiripentol } \\
\hline Chiron et al., $2000^{19}$ & $\begin{array}{l}\text { Randomized, placebo- } \\
\text { controlled }\end{array}$ & 2 & $\begin{array}{l}\text { STP (added } \\
\text { to VPA/ } \\
\text { CLB) }\end{array}$ & $\begin{array}{l}\text { France: } 41 \text { patients: }(20 \text { placebo, } 21 \text { STP }) \\
9 \text { on STP were seizure-free during } 2 \text { nd month } \\
\text { Overall } 69 \% \text { reduction in seizures from baseline compared to } 7 \% \text { increase on placebo } \\
\text { Odds ratio of responding to STP compared to placebo } 32\left(C I_{95 \%}=6.2,161\right)\end{array}$ \\
\hline Inoue et al., $2015^{15}$ & Retrospective & 4 & STP & $13 / 24(54 \%)$ achieved a $>50 \%$ reduction in GTCS; 2 were seizure-free \\
\hline Wirrell et al., $2013^{21}$ & Retrospective & 4 & STP & $\begin{array}{l}82 \text { patients: most children experienced reduction in seizures independent of } \\
\text { whether added to VPA or CLB }\end{array}$ \\
\hline Kassai et al., $2008^{9}$ & Meta-analysis of STP & 1 & & $\begin{array}{l}64 \text { children in } 2 \text { randomized control trials; odds ratio of responding to STP relative } \\
\text { to placebo was } 32\left(C I_{95 \%}=6.2,161\right) \text {, and stiripentol reduced seizures by } 70 \% \\
\left(C I_{95 \%}=93 \%, 47 \%\right)\end{array}$ \\
\hline \multicolumn{5}{|l|}{ Topiramate } \\
\hline Coppola et al., $2002^{10}$ & $\begin{array}{l}\text { Prospective add-on } \\
\text { Median follow-up: } 12 \text { months }\end{array}$ & 3 & TPM & $\begin{array}{l}18 \text { patients: } \\
3 \text { seizure-free } \\
10 \text { had }>50 \% \text { reduction }\end{array}$ \\
\hline Nieto-Barrera et al., $2000^{11}$ & $\begin{array}{l}\text { Prospective add-on } \\
\text { Median follow-up: } 10 \text { months }\end{array}$ & 3 & TPM & $\begin{array}{l}18 \text { patients: } \\
3(16 \%) \text { seizure-free } \\
10(55 \%)>50 \% \text { reduction }\end{array}$ \\
\hline Kroll-Seger et al., $2006^{23}$ & Retrospective & 4 & TPM & $\begin{array}{l}36 \text { patients: } \\
78 \% \text { had }>50 \% \text { reduction in GTCS } \\
17 \% \text { seizure-free for at least } 4 \text { months }\end{array}$ \\
\hline Dressler et al., $2015^{14}$ & Retrospective & 4 & TPM & $35 \%$ responders \\
\hline \multicolumn{5}{|l|}{ Bromides and zonisamide } \\
\hline Oguni et al., $1994^{27}$ & $\begin{array}{l}\text { Add-on } \\
\text { Mean follow-up: } 19 \text { months }\end{array}$ & 4 & Bromide & $\begin{array}{l}22 \text { patients: } \\
8(36 \%)>75 \% \text { reduction } \\
9(41 \%) 50-75 \% \text { reduction in GTCS at } 3 \text { months but only } 8 \text { responders at } 12 \text { months } \\
\text { Less effective for focal or myoclonic/absence seizures }\end{array}$ \\
\hline Tanabe et al., $2008^{26}$ & Retrospective questionnaire & 4 & $\begin{array}{l}\text { Bromides, } \\
\text { ZNS }\end{array}$ & $42 \%$ on bromides and $13.5 \%$ on ZNS had no status epilepticus \\
\hline Lotte et al., $2012^{25}$ & $\begin{array}{l}\text { Retrospective review of } \\
32 \text { patients }\end{array}$ & 4 & Bromides & $\begin{array}{l}\text { After } 3 \text { months, } 81 \% \text { had }>50 \% \text { reduction } \\
\text { At } 12 \text { months, nearly half still had }>50 \% \text { reduction in seizure frequency }\end{array}$ \\
\hline \multicolumn{5}{|l|}{ Levetiracetam } \\
\hline Striano et al., $2007^{24}$ & $\begin{array}{l}\text { Prospective, add-on, open- } \\
\text { label, after } 12 \text {-week } \\
\text { "evaluation" period }\end{array}$ & 3 & LEV & $\begin{array}{l}28 \text { patients: } \\
\text { GTCS: } 3 \text { seizure-free and } 15 \text { with }>50 \% \text { reduction } \\
\text { Myoclonic: } 2 \text { seizure-free and } 7>50 \% \text { reduction } \\
\text { Focal: } 3 \text { seizure-free and } 3>50 \% \text { reduction } \\
\text { Absence: } 1 \text { seizure-free and } 3>50 \% \text { reduction }\end{array}$ \\
\hline \multicolumn{5}{|l|}{ Fenfluramine } \\
\hline Ceulemans et al., $2012^{28}$ & $\begin{array}{l}\text { Retrospective, add-on } \\
\text { Mean follow-up: } 6 \text { years }\end{array}$ & 4 & Fenfluramine & $\begin{array}{l}12 \text { patients: } \\
7 \text { seizure-free for at least } 1 \text { year }\end{array}$ \\
\hline
\end{tabular}

$\mathrm{STP}=$ stiripentol $; \mathrm{VPA}=$ valproate $\mathrm{CLB}=$ clobazam; TPM = topiramate $\mathrm{LEV}=$ levetiracetam; $\mathrm{ZNS}=$ zonisamide; $C I=$ confidence interval; GTCS $=$ generalized tonic-clonic seizure.

*Based on Oxford Centre for Evidence-Based Medicine, $2011 .^{13}$

therapeutic intervention, the level of evidence to support its use in DS will be provided.

\section{First-Line Management: Valproic aCid and Clobazam}

First-line management typically involves either valproic acid or clobazam. Valproic acid is a broad-spectrum agent with multiple possible mechanisms of action, including potentiation of GABAergic function, inhibition of voltage-sensitive sodium channels and antagonism of NMDA receptor-mediated neural excitation. There is minimal literature on its use in DS (level 4), and in retrospective studies ${ }^{14,15}$ responder rates $(>50 \%$ reduction in seizure frequency) were $22.2-48 \%$.

Valproic acid has the potential for several severe adverse effects, including hepatotoxicity (particularly with underlying mitochondrial disease), hyperammonemia, pancreatitis and thrombocytopenia. Additionally, other adverse effects may include decreased or increased appetite, tremor (at higher doses), hair loss and sedation. It is typically started at a dose of $10-15 \mathrm{mg} /$ $\mathrm{kg} / \mathrm{d}$ divided bid to tid, and increased to a target dose of $25-60 \mathrm{mg} / \mathrm{kg} / \mathrm{d}$, depending on achieved blood levels. Monitoring of platelet count and liver function is typically recommended, particularly in younger children. 
Clobazam is a benzodiazepine that is felt to have a lower potential for sedation and acts on the $\mathrm{GABA}_{\mathrm{A}}$ receptor, a pentameric structure with five subunits $(2 \alpha, 2 \beta$, and one $\gamma, \delta, \varepsilon, \theta$ or $\pi)$ around a central pore, through which chloride ions pass, resulting in cellular hyperpolarization. Clobazam acts on the $\gamma$-containing $\mathrm{GABA}_{\mathrm{A}}$ receptors, which are most prevalent, predominantly responsible for fast phasic inhibition and located within the synapse. Clobazam is typically started at doses of $0.2-0.3 \mathrm{mg} / \mathrm{kg} / \mathrm{d}$, with target doses of $0.5-2.0 \mathrm{mg} / \mathrm{kg} / \mathrm{d}$ commonly reached in DS. The main adverse effects of clobazam include behavioural disinhibition, sedation, ataxia and increased salivation. Again, there is a limited amount of data on the efficacy of clobazam in DS (level 4), with a single retrospective study ${ }^{14}$ documenting responder rates of $28 \%$.

Typically, if one first-line agent provides suboptimal control, the other is added on. However, the majority of children will require addition of a second-line agent.

\section{SECOND-Line Therapies}

At present, most epileptologists consider stiripentol, topiramate or the ketogenic diet as the best second-line options for patients who continue to experience poor seizure control despite valproic acid and clobazam.

\section{Stiripentol}

Stiripentol is a positive allosteric modulator of the $\mathrm{GABA}_{\mathrm{A}}$ receptor, acting on both the benzodiazepine-sensitive $\gamma$-containing $\mathrm{GABA}_{\mathrm{A}}$ receptors as well as on the benzodiazepine-insensitive $\delta$-containing $\mathrm{GABA}_{\mathrm{A}}$ receptors, which are predominantly peri- and extrasynaptic in location and responsible for mediating tonic inhibition. ${ }^{16}$ Thus, the combination of stiripentol and benzodiazepines enhances GABAergic neurotransmission beyond the effect of each compound administered alone. Furthermore, in status epilepticus, stiripentol continues to be efficacious, both by maintaining phasic inhibition, due to its action on $\alpha 4$-containing $\mathrm{GABA}_{\mathrm{A}}$ receptors (which are not internalized), and tonic inhibition, by its action on $\delta$-containing $\mathrm{GABA}_{\mathrm{A}}$ receptors. In contrast, pharmacoresistance develops to benzodiazepines due to internalization of the $\mathrm{GABA}_{\mathrm{A}}$ receptors containing the $\gamma 2$ subunit. ${ }^{17}$ Stiripentol has also been shown to have particular affinity for the $\alpha 3$ subunit-containing $\mathrm{GABA}_{\mathrm{A}}$ receptors, which are found at the highest levels in the immature brain. ${ }^{18}$

Stiripentol is approved by Health Canada as adjunctive therapy for refractory generalized tonic-clonic seizures in DS not adequately controlled with valproic acid and clobazam. It is the only agent that has been studied in a randomized, placebo-controlled, blinded manner (level 2). ${ }^{9,19}$ In the pivotal STICLO studies, ${ }^{19}$ children receiving stiripentol added on to clobazam and valproate achieved a $69 \%$ reduction in seizure frequency from baseline, compared to a $7 \%$ increase in those treated with placebo. Overall, the odds ratio of responding to stiripentol compared to placebo was $32\left(C_{95 \%}=6.2\right.$, 161). Other retrospective analyses $4,14,15,20,21$ have confirmed efficacy, with $57-89 \%$ having a $>50 \%$ reduction in seizure frequency, 9-17\% seizure-freedom, and significant reductions in seizure duration, frequency of status epilepticus, frequency of rescue medication use and ER visits.

Stiripentol inhibits CYP2C19, and thus, when used as a co-therapy with clobazam, results in approximately a twofold increase in clobazam levels and a three- to fivefold increase in norclobazam levels. However, subsequent studies $^{22}$ have suggested that the efficacy of stiripentol is independent of its pharmacokinetic interaction with clobazam.

Stiripentol should be combined with valproic acid and/or clobazam, as there are no clinical data to support its use as monotherapy. It is typically started at a dose of $10-15 \mathrm{mg} / \mathrm{kg} / \mathrm{d}$ and titrated up to an initial target dose of approximately $50 \mathrm{mg} / \mathrm{kg} / \mathrm{d}$ over 2-4 weeks. The dose can be further increased as needed to a maximum of $100 \mathrm{mg} / \mathrm{kg} / \mathrm{d}$ in young children, although adolescents and adults require a lower dose $(20-30 \mathrm{mg} / \mathrm{kg} / \mathrm{d})$. Because of the pharmacokinetic interaction, clobazam doses must be reduced, typically to approximately $0.2 \mathrm{mg} / \mathrm{kg} / \mathrm{d}$. The side effects of stiripentol are typically dose-dependent and include somnolence, fatigue, ataxia and decreased appetite. ${ }^{13}$ It is recommended that a complete blood count and liver enzymes be monitored at baseline and then every six months while on therapy.

\section{Topiramate}

Topiramate is a widely available broad-spectrum antiepileptic agent that acts through multiple mechanisms, including blockage of voltage-dependent sodium channels, carbonic anhydrase inhibition, AMPA/kainite receptor antagonism and enhancing $\mathrm{GABA}_{\mathrm{A}}$ activity.

Four modest-sized, observational, open-label, prospective and retrospective studies ${ }^{10,11,14,23}$ assessing the efficacy of topiramate in patients with DS (levels 3 and 4) have shown responder rates of $35-78 \%$, with $10-17 \%$ of patients becoming seizure-free at least in the short term.

Doses used in DS are similar to other epilepsy types, starting at $0.5-2 \mathrm{mg} / \mathrm{kg} / \mathrm{d}$ and increasing to a target of $8-12 \mathrm{mg} / \mathrm{kg} / \mathrm{d}$. Adverse effects include somnolence, decreased appetite, slowing of verbal processing, metabolic acidosis and nephrolithiasis. While topiramate may reduce sweating, thus predisposing to hyperthermia, which is a known seizure trigger in DS, this concern is more theoretical than practical in DS.

\section{Ketogenic Diet (Table 2)}

The ketogenic diet is a well-recognized therapy for medically intractable epilepsy, and several open-label retrospective studies (level 4) 14,28-31 have documented efficacy in DS. Overall, approximately two-thirds of patients are responders, with a minority achieving either freedom from seizure or a marked seizure reduction. In younger children, most centers utilize a traditional ketogenic diet, although the modified Atkins or low-glycemic index options may be more palatable and better tolerated in older children and teens. This diet requires strict adherence and careful supervision by a dietician. Side effects include nausea, vomiting, constipation, nephrolithiasis and hyperlipidemia.

\section{LATER Therapeutic OPTIONS}

Although the data are limited, levetiracetam, bromides or vagal nerve stimulation appear less efficacious than stiripentol, topiramate or the ketogenic diet and should be considered only after failure of these second-line agents.

\section{Levetiracetam}

Levetiracetam, another broad-spectrum antiepileptic medication, whose exact mechanism of action is unknown but which 
Table 2: Ketogenic diet in Dravet Syndrome

\begin{tabular}{|c|c|c|c|}
\hline Study & Study design $(n)$ & Details & Response \\
\hline Caraballo $^{35}$ & Add-on (24) & $\begin{array}{l}\text { Failed a mean of } 6.5 \text { AEDs } \\
\text { Mean age at KD onset: } 6 \text { years }\end{array}$ & $\begin{array}{l}\text { At } 2 \text { years, } 16(67 \%) \text { remain on the diet: } \\
\text { 2: seizure-free } \\
\text { 10: } 75-99 \% \text { improved } \\
\text { 4: } 50-74 \% \text { improved }\end{array}$ \\
\hline Kang et al. ${ }^{36}$ & Add-on (14) & & $\begin{array}{l}10 \text { responders }(>50 \% \text { reduction }) \\
4 \text { non-responders }\end{array}$ \\
\hline Nabbout et al. ${ }^{37}$ & Add-on (15) & $\begin{array}{l}\text { Age at } \mathrm{KD} \text { onset: } \\
\text { 4-11 years } \\
\text { 13/15 SCN1A-positive } \\
\text { All had partial response to AEDs including stiripentol }\end{array}$ & $\begin{array}{l}\text { At } 1 \text { month: } \\
10 / 15 \text { had }>75 \% \text { reduction } \\
8 / 10 \text { maintained response at } 3 \text { and } 6 \text { months } \\
6 / 10 \text { maintained response at } 9 \text { months } \\
\text { All responders showed improved behaviour and attention }\end{array}$ \\
\hline Laux et al. ${ }^{38}$ & Add-on (20) & $\begin{array}{l}\text { All SCN1A-positive } \\
\text { Failed mean of } 5.4 \text { AEDs } \\
\text { Mean age at KD onset: } 2.9 \text { years }\end{array}$ & $\begin{array}{l}13(65 \%) \text { had }>50 \% \text { reduction } \\
6(30 \%) \text { had }>90 \% \text { reduction } \\
\text { Responders showed improved alertness, cognition and behaviour }\end{array}$ \\
\hline
\end{tabular}

$\mathrm{AED}=$ antiepileptic drug; $\mathrm{KD}=$ ketogenic diet.

binds to the synaptic vesicle protein $\mathrm{SV} 2 \mathrm{~A}$, was reported to have a responder rate of $64 \%$ in a single open-label prospective study of 28 patients (level 3 ). ${ }^{24}$ However, other retrospective studies ${ }^{14}$ show significantly lower efficacy-closer to $11 \%$.

It is generally a well-tolerated medication, and its major adverse effect is behavioural disinhibition. Dosing is typically started at $10-20 \mathrm{mg} / \mathrm{kg} / \mathrm{d}$ divided bid to tid, and the dose may be increased to a maximum of $60-80 \mathrm{mg} / \mathrm{kg} / \mathrm{d}$. Routine blood monitoring is not required.

\section{Vagus Nerve Stimulation (Table 3)}

Several relatively small retrospective case series of vagal nerve stimulation in DS are reported, again providing level 4 evidence of efficacy. $^{28,32-37}$ Responder rates are approximately $25-35 \%$ overall, which is lower than what is typically obtained with the ketogenic diet, but they vary significantly between studies.

\section{Bromides}

Bromides were initially used in the 19th century for epilepsy and are currently utilized mostly in veterinary practice. They are not available by prescription in North America. Bromides are given in the form of bromide salts, including potassium bromide, sodium bromide and ammonium bromide.

The exact mechanism of action is not known, but it is presumed that bromides act on the chloride channel of the $\mathrm{GABA}_{\mathrm{A}}$ receptor, causing hyperpolarization. Bromides have shown level 4 efficacy in DS in retrospective studies, ${ }^{15,25-27}$ with responder rates of $37-77 \%$ and seizure-free rates of $9 \%$, although there is a suggestion that response rates taper off over time. Oguni and colleagues ${ }^{27}$ suggested that bromides were most effective for generalized tonic-clonic seizures and less effective for focal, absence or myoclonic seizures. The side effects of bromides are typically minor and include rash, somnolence and decreased appetite.

Table 3: Vagus nerve stimulation in Dravet syndrome

\begin{tabular}{|c|c|c|c|}
\hline Study & Number of patients & Patient details & Response \\
\hline Zamponi et al. ${ }^{39}$ & 8 & $\begin{array}{l}\text { Failed a mean of } 3.2 \text { AEDs } \\
\text { Implanted at mean of } 10.3 \text { years }(S D=6.6)\end{array}$ & $\begin{array}{l}\text { At } 12 \text { months: } \\
5 / 8 \text { had reduction in seizures of } 50-61 \% \\
3 / 8 \text { had no benefit } \\
\text { But all still having monthly seizures }\end{array}$ \\
\hline Rossignol et al. ${ }^{40}$ & 2 & & $\begin{array}{l}1 \text { had }>90 \% \text { reduction } \\
1 \text { no benefit }\end{array}$ \\
\hline Shahwan et al. ${ }^{41}$ & 2 & & $\begin{array}{l}1 \text { had reduction by }>50 \% \\
1 \text { no benefit }\end{array}$ \\
\hline Caraballo $^{35}$ & 3 & Implanted at $13-16$ years & $\begin{array}{l}\text { Followed for } 21-29 \text { months } \\
2 / 350-74 \% \text { reduction } \\
1 / 3 \text { no benefit }\end{array}$ \\
\hline Spatola et al. ${ }^{42}$ & 1 & Implanted at age 19 years & At 3 months, $1 / 1$ had $>90 \%$ reduction \\
\hline Bremer et al. ${ }^{43}$ & 13 & & $\begin{array}{l}1 / 13 \text { responder ( }>50 \% \text { reduction }) \\
12 / 13 \text { non-responders }\end{array}$ \\
\hline Orosz et al. $^{44}$ & 20 & & $\begin{array}{l}\text { Responder rates }(>50 \% \text { reduction in seizures) } \\
6 \text { months, } 2 / 16(12.5 \%) \text {; at } 12 \text { months, } 5 / 20(25 \%) \\
24 \text { months, } 5 / 13(38.5 \%)\end{array}$ \\
\hline
\end{tabular}

$\mathrm{AED}=$ antiepileptic drug; $S D=$ standard deviation. 


\section{Agents in DeVelopment}

\section{Fenfluramine}

Fenfluramine, an agent that releases serotonin by disrupting vesicular storage and reversing serotonin transporter function, has been reported in a single level 4 study $^{28}$ of 12 patients to have remarkable efficacy in DS. Patients were treated for a mean of 11.4 years. Ten $(83 \%)$ continued on fenfluramine at follow-up and seven (58\%) were seizure-free for longer than a year. Fenfluramine combined with phentermine (Fen-Phen) was previously used as an anti-obesity treatment and was pulled off the market due to cardiac valvulopathy. However, in a Belgian study of DS, ${ }^{28}$ mild heart valve thickening was seen in only two cases and was not progressive. A randomized placebo-controlled phase 3 study followed by a long-term open-label extension study of fenfluramine in DS is presently underway.

\section{Cannabidiol}

Despite much media attention, there are few reports in the literature that evaluate the efficacy of cannabinoids in DS. In a retrospective chart review ${ }^{29}$ of 13 children with DS in a single center in Colorado who trialed various strains of oral cannabis extract, only $3(23 \%)$ were responders. Somewhat more encouraging results were obtained in a multicenter open-label study of 25 patients ${ }^{30}$ with DS who received $>99 \%$ pure oil-based cannabidiol extract. After three months of treatment, the overall seizure frequency was reduced by $63 \%$ and $16 \%$ were seizurefree. A randomized placebo-controlled study of plant-based cannabidiol has just been completed, with early results showing it to be more efficacious than placebo. Overall, patients randomized to cannabidiol experienced a $39 \%$ reduction in monthly convulsive seizures compared to only $16 \%$ in the placebo group $(p=0.01)$ (gwpharma.com), although the results are not yet published.

\section{Management of Status EPILEPTICUS}

All patients with Dravet syndrome are at risk of status epilepticus and should be provided with a home-rescue medication (diazepam, midazolam or lorazepam). In addition, each patient with DS should also have an individualized status epilepticus protocol, which can be carried out at their local emergency room. Based on a survey of 99 patients with DS from Japan, ${ }^{26}$ efficacy for termination of ongoing status epilepticus was best with intravenous barbiturates (75-100\%), modest with intravenous benzodiazepines (54.3-68.8\%) and relatively low with intravenous lidocaine or phenytoin (15.4-21.4\%).

\section{Treatment OF Other Co-Morbidities}

Seizures in DS are clearly problematic, but they represent only one aspect of this disorder. While children are typically developmentally normal at seizure onset, nearly all develop intellectual disability over time. ${ }^{2}$ Additionally, behavioural, sleep and psychological issues are problematic. ${ }^{31,32}$ By adolescence, many develop a typical "crouch gait." 33,34 Multidisciplinary team involvement-including neuropsychology, physical, occupational and speech therapy, and social work-is essential to maximize the quality of life and well-being for the patient with DS and their family.

\section{DisCLOSURES}

Elaine Wirrell has the following disclosures: GW Pharma, site investigator (no financial compensation received, all monies going to the Mayo Clinic); Biocodex, other (research support), honoraria.

\section{REFERENCES}

1. Wolff M, Casse-Perrot C, Dravet C. Severe myoclonic epilepsy of infants (Dravet syndrome): natural history and neuropsychological findings. Epilepsia. 2006;47(Suppl 2):45-8.

2. Ragona F, Granata T, Dalla Bernardina B, Offredi F, Darra F, Battaglia D, et al. Cognitive development in Dravet syndrome: a retrospective, multicenter study of 26 patients. Epilepsia. 2011;52(2):386-92.

3. Nabbout R, Chemaly N, Chipaux M, Barcia G, Bouis C, Dubouch C, et al. Encephalopathy in children with Dravet syndrome is not a pure consequence of epilepsy. Orphanet J Rare Dis. 2013;8:176.

4. Thanh TN, Chiron C, Dellatolas G, Rey E, Pons G, Vincent J, et al. Long-term efficacy and tolerance of stiripentol in severe myoclonic epilepsy of infancy (Dravet syndrome) [in French]. Arch Pediatr. 2002;9(11):1120-7.

5. Guerrini R, Dravet C, Genton P, Belmonte A, Kaminska A, Dulac O, et al. Lamotrigine and seizure aggravation in severe myoclonic epilepsy. Epilepsia. 1998;38(5):508-12.

6. Chipaux M, Villeneuve N, Sabouraud P, Desguerre I, Boddaert N, Depienne $\mathrm{C}$, et al. Unusual consequences of status epilepticus in Dravet syndrome. Seizure. 2010;19(3):190-4.

7. Ceulemans B. Overall management of patients with Dravet syndrome. Dev Med Child Neurol. 2011;53(Suppl 2):19-23.

8. Mueller A, Boor R, Coppola G, Striano P, Dahlin M, von Stuelpnagel C, et al. Low long-term efficacy and tolerability of add-on rufinamide in patients with Dravet syndrome. Epilepsy Behav. 2011;21(3):282-4.

9. Kassai B, Chiron C, Augier S, Cucherat M, Rey E, Gueyffier F, et al. Severe myoclonic epilepsy in infancy: a systematic review and a meta-analysis of individual patient data. Epilepsia. 2008;49(2): 343-8.

10. Coppola G, Caliendo G, Veggiotti P, Romeo A, Tortorella G, De Marco P, et al. Topiramate as add-on drug in children, adolescents and young adults with Lennox-Gastaut syndrome: an Italian multicentric study. Epilepsy Res. 2002;51(1-2):147-53.

11. Nieto-Barrera M, Candau R, Nieto-Jimenez M, Correa A, del Portal LR. Topiramate in the treatment of severe myoclonic epilepsy in infancy. Seizure. 2000;9(8):590-4.

12. Striano P, Elefante A, Coppola A, Tortora F, Zara F, Minetti C, et al. Dramatic response to levetiracetam in post-ischaemic Holmes' tremor. J Neurol Neurosurg Psychiatry. 2007;78(4):438-9.

13. Centre for Evidence-Based Medicine. The Oxford 2011 Levels of Evidence. 2011. Available from: http://www.cebm.net/ocebm-levelsof-evidence/.

14. Dressler A, Trimmel-Schwahofer P, Reithofer E, Mühlebner A, Gröppel G, Reiter-Fink E, et al. Efficacy and tolerability of the ketogenic diet in Dravet syndrome: comparison with various standard antiepileptic drug regimen. Epilepsy Res. 2015;109:81-9.

15. Inoue Y, Ohtsuka Y, STP-1 Study Group. Long-term safety and efficacy of stiripentol for the treatment of Dravet syndrome: a multicenter, open-label study in Japan. Epilepsy Res. 2015;113:90-7.

16. Fisher JL. The effects of stiripentol on $\mathrm{GABA}_{\mathrm{A}}$ receptors. Epilepsia. 2011;52(Suppl 2):76-8.

17. Grosenbaugh DK, Mott DD. Stiripentol in refractory status epilepticus. Epilepsia. 2013;54(Suppl 6):103-5.

18. Fisher JL. The anti-convulsant stiripentol acts directly on the $\mathrm{GABA}_{\mathrm{A}}$ receptor as a positive allosteric modulator. Neuropharmacology. 2009;56:190-7.

19. Chiron C, Marchand MC, Tran A, Rey E, d'Athis P, Vincent J, et al. Stiripentol in severe myoclonic epilepsy in infancy: a randomised placebo-controlled syndrome-dedicated trial. STICLO study group. Lancet. 2000;356(9242):1638-42.

20. Inoue Y, Ohtsuka Y. Effectiveness of add-on stiripentol to clobazam and valproate in Japanese patients with Dravet syndrome: additional supportive evidence. Epilepsy Res. 2014;108(4):725-31. 
21. Wirrell EC, Laux L, Franz DN, Sullivan J, Saneto RP, Morse RP, et al. Stiripentol in Dravet syndrome: results of a retrospective U.S. study. Epilepsia. 2013;54(9):1595-604.

22. Kouga T, Shimbo H, Iai M, Yamashita S, Ishii A, Ihara Y, et al. Effect of CYP2C19 polymorphisms on stiripentol administration in Japanese cases of Dravet syndrome. Brain Dev. 2015; 37(2):243-9.

23. Kroll-Seger J, Portilla P, Dulac O, Chiron C. Topiramate in the treatment of highly refractory patients with Dravet syndrome. Neuropediatrics. 2006;37(6):325-9.

24. Striano P, Coppola A, Pezzella M, Ciampa C, Specchio N, Ragona F, et al. An open-label trial of levetiracetam in severe myoclonic epilepsy of infancy. Neurology. 2007;69(3):250-4.

25. Lotte J, Haberlandt E, Neubauer B, Staudt M, Kluger GJ. Bromide in patients with SCN1A mutations manifesting as Dravet syndrome. Neuropediatrics. 2012;43(1):17-21.

26. Tanabe T, Awaya Y, Matsuishi T, Iyoda K, Nagai T, Kurihara M, et al. Management of and prophylaxis against status epilepticus in children with severe myoclonic epilepsy in infancy (SMEI; Dravet syndrome): a nationwide questionnaire survey in Japan. Brain Dev. 2008;30(10):629-35.

27. Oguni H, Hayashi K, Oguni M, Mukahira A, Uehara T, Fukuyama Y, et al. Treatment of severe myoclonic epilepsy in infants with bromide and its borderline variant. Epilepsia. 1994;35(6):1140-5.

28. Ceulemans B, Boel M, Leyssens K, Van Rossem C, Neels P, Jorens PG, et al. Successful use of fenfluramine as an add-on treatment for Dravet syndrome. Epilepsia. 2012;53(7):1131-9.

29. Press CA, Knupp KG, Chapman KE. Parental reporting of response to oral cannabis extract for treatment of refractory epilepsy. Epilepsy Behav. 2015;45:49-52.

30. Devinsky O, Sullivan J, Friedman D, Thiele E, Marsh E, Laux L, et al. Epidiolex (cannabidiol) in treatment-resistant epilepsy. Available from: http://www.gwpharm.com/uploads/cbdposteraan-r_ 08apr2015.pdf.

31. Dhamija R, Erickson MK, St Louis EK, Wirrell E, Kotagal S. Sleep abnormalities in children with Dravet syndrome. Pediatr Neurol. 2014;50(5):474-8.

32. Skluzacek JV, Parsy O, Wical B, Camfield P. Dravet syndrome and parent associations: the IDEA League experience with comorbid conditions, mortality, management, adaptation, and grief. Epilepsia. 2011;52(Suppl 2):95-101.

33. Rilstone JJ, Coelho FM, Minassian BA, Andrade DM. Dravet syndrome: seizure control and gait in adults with different SCN1A mutations. Epilepsia. 2012;53(8):1421-8.

34. Rodda JM, Scheffer IE, McMahon JM, Berkovic SF, Graham HK. Progressive gait deterioration in adolescents with Dravet syndrome. Arch Neurol. 2012;69(7):873-8.

35. Caraballo RH. Nonpharmacologic treatments of Dravet syndrome: focus on the ketogenic diet. Epilepsia. 2011;52(Suppl 2): 79-82.

36. Kang HC, Kim HD, Kim DW. Short-term trial of a liquid ketogenic milk to infants with West syndrome. Brain Dev. 2006;28(1):67.

37. Nabbout R, Copioli C, Chipaux M, Chemaly N, Desguerre I, Dulac $\mathrm{O}$, et al. Ketogenic diet also benefits Dravet syndrome patients receiving stiripentol: a prospective pilot study. Epilepsia. 2011; 52(7): 5 54-7.

38. Laux L, Blackford R. The ketogenic diet in Dravet syndrome. J Child Neurol. 2013;28(8):1041-4.

39. Zamponi N, Passamonti C, Cappanera S, Petrelli C. Clinical course of young patients with Dravet syndrome after vagal nerve stimulation. Eur J Paediatr Neurol. 2011;15(1):8-14.

40. Rossignol E, Lortie A, Thomas T, Bouthiller A, Scavarda D, Mercier C, et al. Vagus nerve stimulation in pediatric epileptic syndromes. Seizure. 2009;18(1):34-7.

41. Shahwan A, Bailey C, Maxiner W, Harvey AS. Vagus nerve stimulation for refractory epilepsy in children: more to VNS than seizure frequency reduction. Epilepsia. 2009;50(5):1220-8.

42. Spatola M, Jeannet PY, Pollo C, Wider C, Labrum R, Rossetti AO. Effect of vagus nerve stimulation in an adult patient with Dravet syndrome: contribution to sudden unexpected death in epilepsy risk reduction? Eur Neurol. 2013;69(2):119-21.

43. Bremer A, Lossius MI, Nakken KO. Dravet syndrome: considerable delay in making the diagnosis. Acta Neurol Scand. 2012; 125(5):359-62.

44. Orosz I, McCormick D, Zamponi N, Varadkar S, Feucht M, Parain $\mathrm{D}$, et al. Vagus nerve stimulation for drug-resistant epilepsy: a European long-term study up to 24 months in 347 children. Epilepsia. 2014;55(10):1576-84. 